\title{
American Eskimo Dog
}

National Cancer Institute

\section{Source}

National Cancer Institute. American Eskimo Dog. NCI Thesaurus. Code C53845.

The American Eskimo is a white Spitz-type dog. It has a wedge-shaped head with muzzle and skull about the same length. It has erect triangular-shaped ears and a heavily plumed tail curled over the back. The profuse coat is always white, or white with biscuit or cream markings. Toy: 9-12 inches (23-30 cm) 6-10 pounds (2.4-4.5 kg) Miniature: over 12 (30 $\mathrm{cm}$ ) up to 15 inches $(38 \mathrm{~cm}) 10-20$ pounds $(4.5-9 \mathrm{~kg}$ ) Standard: over 15 inches $(38 \mathrm{~cm})$ up to 19 inches $(48 \mathrm{~cm}) 18-35$ pounds (8-16 kg.) 